Submitted, accepted and published in

International Journal of Hydrogen Energy 39, 5371-5377 (2014);

DOI: 10.1016/j.ijhydene.2013.12.198

\title{
1 Fuel Cell Performance of Pt Electrocatalysts Supported on
}

a Instituto de Carboquímica (CSIC), Miguel Luesma Castán 4, 50018 Zaragoza, Spain

b Departamento de Química Física, Universidad de La Laguna, Avda. Astrofísico Francisco Sánchez s/n, 38071 La Laguna,Tenerife, Spain

\author{
V. Celorrio ${ }^{\mathrm{a}, 1}$, J. Flórez-Montaño ${ }^{\mathrm{b}}$, R. Moliner ${ }^{\mathrm{a}}$, E. Pastor $^{\mathrm{b}}$, M.J. Lázaro ${ }^{\mathrm{a}}{ }^{*}$
}

* Corresponding author: Tel. +34 976 733977; Fax: +34 976 733318; E-mail address:

mlazaro@icb.csic.es

${ }^{1}$ Present Address: School of Chemistry, University of Bristol, Cantocks Close, Bristol 7 BS8 1TS, United Kingdom 


\section{Abstract}

2 Carbon nanocoils (CNCs) synthesized via the catalytic graphitization of resorcinol-

3 formaldehyde gel were investigated as an electrocatalyst support in PEMFC anodes.

$4 \quad$ Their textural and physical properties make them a highly efficient catalyst support for

5 anodic hydrogen oxidation in low temperature PEMFC.

6 When the oxidation of adsorbed CO was studied, a shift of $140 \mathrm{mV}$ is observed 7 compared with the commercial catalysts (Pt/C E-TEK) which is expected to be a key 8 parameter in the fuel cell (PEM) performance. Furthermore, the behaviour of the 9 electrocatalysts prepared was compared with that of a Pt/C E-TEK in a $5 \mathrm{~cm}^{2}$ PEM fuel cell. At room temperature, results showed a $4 \%$ increase in current density at $0.6 \mathrm{~V}$ in

11 comparison with the Pt/C E-TEK electrocatalysts. 


\section{Introduction}

Current air pollution and the dwindling resources of hydrocarbons necessitate the search of new generator and accumulation energy systems in order to secure and diversify energy supplies and reduce $\mathrm{CO}_{2}$ emissions. Within this context, fuel cells appear to be an alternative energy conversion technology [1-3]. Among the different types of fuel cells, polymer electrolyte (PEMFCs) and direct alcohol (DAFCs) technologies are more suited for use in portable electrical devices due to their low operating temperatures $\left(60-100{ }^{\circ} \mathrm{C}\right)$ and fast start up [4-6].

Common catalysts used at the anodic side of these cells are platinum and platinum alloys $[7,8]$. Considering that catalysis is a surface phenomenon, an aspect to be taken into account in the design of a catalyst is a high surface area. For this purpose, the active catalyst phase is dispersed in a conductive support, typically carbon materials. However, the development of PEMFCs, from the viewpoint of the electrocatalyst, is limited by the poisoning of the anode catalyst by $\mathrm{CO}$, which is present as an impurity in the reformed gas used as a $\mathrm{H}_{2}$ source for this type of cells. In the presence of 50-100 ppm of $\mathrm{CO}$ in the fuel, Pt-Ru alloys supported on carbon materials have shown an electrocatalytic activity higher than pure Pt [9]. On the cathodic side, Pt is showing the highest catalytic activity towards oxygen reduction reaction [10,11]. Durability is another key factor for the commercialization of low temperature fuel cells. Over the past years, extensive research and development efforts have been directed towards optimizing the initial performance of catalysts, membranes and gas diffusion layers, but only recent research has focused on the various material degradation mechanisms observed over the life-time of fuel cells under real conditions $[12,13]$.

Carbon materials are generally used as catalyst supports because of their stability in both acidic and basic media, good electrical conductivity, high corrosion resistance, 
1 surface properties and high specific surface area [14-17]. Activated carbons, carbon

2 blacks, graphites and graphitized materials have been applied in various catalytic

3 processes. Carbon materials have a strong influence on the properties of supported

4 noble metal catalysts, such as metal particle size, morphology, size distribution,

5 stability, and dispersion $[18,19]$. On the other hand, carbon supports can also affect the

6 performance of fuel cell catalysts by altering mass transport, catalyst layer electrical

7 conductivity, electrochemically active area, and metal nanoparticle stability during

8 operation [20, 21]. Consequently, a carbon support with suitable properties must be

9 selected in order to obtain an active catalyst, since its properties have strong effects on

10 the preparation and performance of supported catalysts.

11 Among all types of carbon materials, carbon blacks are the most used as electrocatalytic support for PEMFCs, due to their high electrical conductivity, corrosion resistance, their porous structure and specific surface area [22]. Vulcan XC-72 is extensively used as an electrocatalyst support [23, 24]. At present, this material is used as support in commercial electrocatalysts (E-TEK and Johnson Matthey). However, it shows high ohmic resistance and problems of mass transfer in fuel cell applications.

As carbon supports have been found to strongly influence the accessibility of the catalytic active sites, great efforts are being made to find the optimum architecture of carbon supports. In recent years, an important strategy to reduce the performance degradation due to mass transport resistance has been the use of alternative carbon supports with a suitable mesoporous structure. Novel non-conventional carbon materials with controllable porous structures and surface chemistry, such as carbon nanocoils [25], carbon xerogels and aerogels [26], and ordered mesoporous carbons [27], have been proposed as electrocatalyst supports. However, a critical aspect is to achieve a balance between specific surface area, pore size distribution and electrical conductivity. 
2 for PEMFC. To validate its applicability in practical fuel cells, performance of the

3 supported catalysts is evaluated in a working fuel cell environment and compared to

4 those of commercially available carbon blacks.

\section{2. Experimental}

\section{$7 \quad$ 2.1. Carbon nanocoils (CNCs) and catalysts preparation}

Carbon nanocoils were synthesized by the catalytic graphitization of resorcinol-

9 formaldehyde gel as described elsewhere [28]. In a typical synthesis, formaldehyde (Sigma-Aldrich) and silica sol (Supelco) were dissolved in $100 \mathrm{~mL}$ of deionized water, and then a mixture of nickel $\left(\mathrm{Ni}\left(\mathrm{NO}_{3}\right)_{2} \cdot 6 \mathrm{H}_{2} \mathrm{O}\right.$, Panreac $)$ and cobalt $\left(\mathrm{Co}\left(\mathrm{NO}_{3}\right)_{2} \cdot 6 \mathrm{H}_{2} \mathrm{O}\right.$, Sigma-Aldrich) salts was added under stirring conditions. Subsequently, resorcinol (Sigma-Aldrich) was added, and the stirring conditions maintained for $0.5 \mathrm{~h}$. After a heat treatment at $85{ }^{\circ} \mathrm{C}$ for $3 \mathrm{~h}$ in a closed system of this reaction mixture, the system was then opened, and the mixture dried at $108{ }^{\circ} \mathrm{C}$. Finally it was carbonized in a nitrogen atmosphere at $900{ }^{\circ} \mathrm{C}$ for $3 \mathrm{~h}$. A $5 \mathrm{M} \mathrm{NaOH}$ (Panreac) solution was used to remove silica particles, followed by a treatment with concentrated nitric acid $(65 \%$, Fluka) at room temperature during $2 \mathrm{~h}$ to remove the metal salts [29].

Pt particles supported on the different carbon materials were synthesized by the impregnation and subsequent reduction with sodium borohydride method. The amount of platinum precursor added was calculated to obtain a load of $20 \mathrm{wt} . \% \mathrm{Pt} / \mathrm{C}$ in the catalyst. A solution of the metal salt precursor was prepared and mixed with the carbon support. After the impregnation step, a reduction step is required to reduce the catalyst precursor to its metallic state, using sodium borohydride as reducing agent $(99 \%$, 
1 reagent (8 wt. $\% \mathrm{H}_{2} \mathrm{PtCl}_{6} \cdot 6 \mathrm{H}_{2} \mathrm{O}$ solution, Sigma-Aldrich) and ultrapure water (Milli-Q).

2 Firstly the precursor solution is slowly added to a dispersion of carbon in ultrapure

3 water under sonication and afterwards the $\mathrm{pH}$ of the dispersion is adjusted to 5.0. Then,

4 the sodium borohydride aqueous solution $(26.5 \mathrm{mM})$ is dropwise added, maintaining

5 temperature under $18{ }^{\circ} \mathrm{C}$ and in the presence of sonication. Subsequently, the catalyst is

6 filtered and thoroughly washed with ultrapure water, and then dried overnight at $60{ }^{\circ} \mathrm{C}$

$7 \quad[27,30]$.

$8 \quad$ 2.2. Carbon materials and catalysts characterization

The textural characteristics of the carbon materials were derived from the $\mathrm{N}_{2}$ adsorption-desorption isotherms obtained at $-196^{\circ} \mathrm{C}$ in a Micromeritics ASAP 2020 volumetric adsorption system. Specific surface area was calculated using the BET (Brunauer-Emmett-Teller) equation. Total pore volume was determined by the single point method at $\mathrm{p} / \mathrm{p}_{0}=0.99$. Micropore volume was assessed by applying the t-plot method.

Transmission electron microscopy (TEM) has been carried out on a JEOL JEM 2010F microscope operating at $200 \mathrm{kV}$.

X-ray diffraction patterns were recorded using a BrukerAXS B8 Advance diffractometer with $\theta-\theta$ configuration and operating with $\mathrm{Cu} \mathrm{K} \alpha$ radiation $(\lambda=0.15406$ $\mathrm{nm})$ generated at $45 \mathrm{kV}$ and $40 \mathrm{~nm}$. The crystallite size of the supported $\mathrm{Pt}$ was determined from the (2 20 ) width peak around $2 \theta=70^{\circ}$, which corresponds to its fcc structure, to avoid the influence of the broad band of the carbon support at $2 \theta \sim 25^{\circ}$ [ 31 , 32] and the deconvolution of the ( $\left(\begin{array}{lll}1 & 1 & 1\end{array}\right)$ and ( $\left.\begin{array}{lll}2 & 0 & 0\end{array}\right)$ reflections. In this case, a value of $\mathrm{k}$ $=0.9$ was used. Bragg's law was also applied to the $\left(\begin{array}{l}2 \\ 2\end{array}\right.$ 0) peak of the Pt fcc structure in order to estimate the Pt lattice parameters. 
2 cell using a MicroAutolab potentiostat. The counter electrode was a large area pyrolitic

3 graphite bar and a reversible hydrogen electrode (RHE) placed inside a Luggin capillary

4 was used as reference. Working electrodes were prepared depositing a thin layer of the

5 electrocatalysts over a pyrolitic graphite disk $(7 \mathrm{~mm}$ diameter). A catalyst ink was

6 prepared by mixing $2 \mathrm{mg}$ of the catalyst and $10 \mu \mathrm{l}$ of Nafion dispersion ( $5 \mathrm{wt} . \%$, Aldrich)

7 in $500 \mu 1$ of ultrapure water (Millipore Milli-Q system). A $40 \mu 1$ aliquot of the suspension

8 was deposited onto the graphite disk and dried. After that, the working electrode was

9 immersed into $\mathrm{H}_{2} \mathrm{SO}_{4} 0.5 \mathrm{M}$ electrolyte solution, prepared from high purity reagents

10 (Merck) and deaerated with nitrogen gas. All the electrochemical experiments presented

11 in this work were carried out at room temperature (T). CO (99.99\%) was adsorbed onto the metal surface by bubbling this gas at 1 atm through the electrolyte to achieve a full monolayer coverage of $\mathrm{CO}$. The $\mathrm{CO}$ adsorption process was carried out at a constant potential of $0.2 \mathrm{~V}$ vs RHE ( $\left.\mathrm{E}_{\mathrm{ad}}\right)$. Subsequently, $\mathrm{N}_{2}$ gas was used to purge out the CO from the solution, leaving only the $\mathrm{CO}$ adsorbed on the metal surface. Moreover, the electroactive area of catalysts was determined by the integration of the $\mathrm{CO}_{\mathrm{ad}}$ peak assuming a charge density of $420 \mu \mathrm{C} \mathrm{cm}^{-2}$ involved in the oxidation of a monolayer of linearly adsorbed CO. These electroactive areas were used to normalize the current densities given in the text.

\subsection{Performance at the anode side of a PEM fuel cell}

Electrochemical tests of Membrane Electrode Assemblies (MEAs) were performed in a testing station fuel cell Bio-Logic FCT-50. Catalysts were tested at the anode side in a home-made PEM fuel cell $\left(5 \mathrm{~cm}^{2}\right.$ geometric areas). Tests were carried out at room temperature or $40{ }^{\circ} \mathrm{C}$ and atmospheric pressure. Pure hydrogen and oxygen 
1 (purity $>99.9 \%$ ) were passed through humidifiers and fed at the anode and cathode

2 sides, respectively. The flow rate used for either $\mathrm{N}_{2}$ or $\mathrm{O}_{2}$ was $0.10 \mathrm{~L} \mathrm{~min}^{-1}$.

In these tests, the MEA is inserted between two graphite bipolar plates with a coil-shaped flow-field layout; this is then inserted between the gold-plated stainless steel collector plates. The assembly is completed with two steel end plates, with inlets and outlets for the reactants and reaction products and the heat system.

Before the MEAs preparation, the polymer electrolyte membrane, Nafion ${ }^{\circledR} 115$ (Du Pont Chemical), was cleaned by immersing in $3 \% \mathrm{H}_{2} \mathrm{O}_{2}$ for $1 \mathrm{~h}$ at $80{ }^{\circ} \mathrm{C}$ to remove organic impurities and subsequently, in a $0.5 \mathrm{M} \mathrm{H}_{2} \mathrm{SO}_{4}$ solution for $1 \mathrm{~h}$ at $80{ }^{\circ} \mathrm{C} . \mathrm{H}_{2} \mathrm{SO}_{4}$ was removed by washing in boiling distilled water.

In order to carry out the electrochemical measurements, several MEAs were prepared using different electrodes for the anode side, and an electrode based on the commercial $20 \% \mathrm{Pt} / \mathrm{C}$ electrode (E-TEK Inc.) for the cathode side. The electrodes were prepared by depositing a suspension of Nafion solution (10\% wt.) and the synthesised electrocatalyst (Nafion content in the suspension $=32 \% \mathrm{wt}$ ) on pieces of E-TEK ELAT carbon cloth. The final amount of metal active phase in all the prepared electrodes was $0.4 \mathrm{mg} \mathrm{cm}^{-2}$

The final assembly of the electrodes and the Nafion membrane was hot pressed between two metallic plates and heated at $120{ }^{\circ} \mathrm{C}$, with a pressure of $20 \mathrm{Kg} \mathrm{cm}^{-2}$ for 90 s. Characteristic polarization curves V (cell potential) versus $j$ (current density) for each of the prepared MEAs were measured under strictly comparable conditions.

\section{Results}

\subsection{Carbon materials and catalysts characterization}


2 work [28]. CNCs present a specific surface area of $124 \mathrm{~m}^{2} \mathrm{~g}^{-1}$ and a total pore volume of

$3 \quad 0.16 \mathrm{~cm}^{3} \mathrm{~g}^{-1}$, which correspond to interparticular spaces. They show a bimodal pore size

4 distribution in the range of mesoporosity with average pore diameters of around 3 and

$515 \mathrm{~nm}$, and do not contain micropores. Vulcan XC-72R has a specific surface area of

$6218 \mathrm{~m}^{2} \mathrm{~g}^{-1}$ and a pore volume of $0.41 \mathrm{~cm}^{3} \mathrm{~g}^{-1}$ [33]. It has a mesoporous structure but

7 also contained a large amount of micropores (30\% of the total surface area). It has a

8 broad pore size distribution with pores of less than $2 \mathrm{~nm}$ and more than $12 \mathrm{~nm}$.

Table 1 shows the nomenclature and the metal loading of the different electrocatalysts obtained by EDX. As can be seen, average metal loadings were close to the nominal value of $20 \% \mathrm{wt}$.

The morphological and crystallographic properties of the carbon materials and metal catalysts were studied by X-ray diffraction, XRD patterns are reported in Figure 1. CNCs show three peaks at $2 \theta$ of $26.24^{\circ}, 43.85^{\circ}$ and $54.29^{\circ}$ which are attributed to the (002), (100) and (004) reflections of graphitic carbon (Figure 1.a). Vulcan also shows the (002) reflection although it appears broader and shifted to lower angles $\left(24.6^{\circ}\right)$, indicative of their more amorphous character. All the Pt-supported electrocatalysts showed the typical form of the face centered cubic (fcc) Pt structure, indicating the effective reduction of the metal precursor, producing crystalline nanoparticles (Figure 1.b). Peaks at $2 \theta=40^{\circ}, 47^{\circ}, 67^{\circ}, 81^{\circ}$ and $85^{\circ}$, associated with the Pt crystal planes (111), (200), (220), (311) and (222), respectively, were observed.

Average metal crystallite sizes of the electrocatalysts were calculated using the Scherrer equation to the (220) XRD peak and are reported in Table 1. Bigger platinum crystallite size was obtained when CNCs were used as support. Graphitized carbons, 
1 like CNCs, have a low number of nucleation sites because only the surface defects can

2 function as nucleation sites, and thus larger Pt particles are obtained.

The lattice parameters were also calculated from XRD patterns and the results are summarized in Table 1. This value decreases with increasing the crystallite size. The dependence of the lattice parameter on the crystallite size has been described previously in the literature $[34,35]$. A linear dependence between the lattice parameter and the crystallite size has been observed depending on the synthesis method used to prepare $\mathrm{Pt} / \mathrm{C}$ catalysts. However, in this work, to state a solid conclusion, more catalysts should be synthesised by using the same and different methods.

Figure 2 shows a TEM image obtained for the Pt catalysts supported on CNCs. A good distribution of the platinum particles was attained.

\subsection{Oxidation of adsorbed CO}

$\mathrm{CO}$ poisoning in the anode of PEMFCs is a problem in the development and subsequent operation of this type of devices. $\mathrm{CO}$ is strongly adsorbed on the metal surface, disabling the active sites for further oxidation of the fuel, causing the poisoning of the catalyst. In order to establish the $\mathrm{CO}$ tolerance of catalysts, the electro-oxidation of a CO monolayer adsorbed on the catalyst surface was studied.

Figure 3 shows the CO-stripping voltammograms for Pt catalysts (solid line), as well as the second cycle (dashed line) after oxidation, which corresponds to the voltammogram in the base electrolyte for the clean surface at $0.020 \mathrm{~V} \mathrm{~s}^{-1}(\mathrm{v})$. In the first scan, when the Pt surface is blocked by the adsorption of a $\mathrm{CO}$ monolayer $\left(\mathrm{CO}_{\mathrm{ads}}\right)$, hydrogen adsorption becomes impossible. In the second scan, well known reactions occur at the surface of the Pt electrode. At potentials higher than approximately $0.8 \mathrm{~V}$, the Pt surface is oxidized to $\mathrm{PtOH}$ and $\mathrm{PtOx}$ in the anodic potential scan direction, and 
1 these Pt oxides are reduced to metallic Pt in the cathodic potential scan direction. At

2 potentials less positive than approximately $0.3 \mathrm{~V}$, once the $\mathrm{CO}$ layer is removed, two

3 pair of peaks are observed due to the hydrogen adsorption and desorption.

Similar results were obtained for $\mathrm{Pt} /$ Vulcan and commercial $\mathrm{Pt} / \mathrm{C}$ E-TEK catalysts, which feature a relatively narrow $\mathrm{CO}_{\text {ads }}$ oxidation peak centered at $0.84 \mathrm{~V}$. CNCs supported Pt particles exhibited a current peak at $0.70 \mathrm{~V}$, with an additional shoulder at around $0.76 \mathrm{~V}$. There is no clear consensus on the origin of multiple oxidation peaks at nanostructured Pt electrodes [36-38]. On the other hand, the shift of the $\mathrm{CO}_{\text {ads }}$ oxidation peak towards more negative values for the CNCs supported nanoparticles can be rationalized in terms of particle size. It is generally accepted in literature that the $\mathrm{CO}$ oxidation peak shifts negatively while increasing Pt particle size $[37,39,40]$. The key step in the oxidation of a monolayer of CO on Pt is the reaction of an oxidized Pt surface atom with an adjacent adsorbed $\mathrm{CO}$ molecule. The formation of oxidized Pt sites becomes more difficult as the Pt size decreases, resulting in a positive shift of the oxidation peak potential.

\subsection{Performance of fuel cell with synthesized electrocatalysts in electrodes}

It is well known that at low temperature, the catalysts (including the supports) have a dominating effect on the performance of fuel cells, and comparisons of performance at relatively low temperatures are the most practical and powerful ways of evaluating the activity of catalysts.

Figure 4 shows the polarization (cell potential versus current density) and power density curves obtained at room temperature (a) and $40^{\circ} \mathrm{C}$ (b), using the catalysts under study at the anode and the Pt commercial catalyst (E-TEK) at the cathode sides. Pt/CNC based MEA showed the best performance, even better than the MEA based on the commercial electrode (Pt/C E-TEK), because it gave lower polarization losses. Taking 
1 into account that all experiments were carried out in the same experimental system and

2 using the same membrane, differences in the performance of electrodes may be

3 attributed to the mesoporous structure of CNCs, which favours the triple-phase contact

4 of reactant gas, catalyst, and the membrane, where the electrochemical reaction takes

5 place $[41,42]$. Therefore, the least voltage drop with $\mathrm{Pt} / \mathrm{CNC}$ based electrode may be

6 associated to a more efficient use of metal particles. The larger amount of mesopores

7 present in CNCs could promote the diffusion of reactants and products, and this is

8 advantageous for their application in electrocatalysis.

As can be observed, at $0.60 \mathrm{~V}$, an ohmic polarization regime dominates the activity of the catalyst; the current density $\left(291 \mathrm{~mA} \mathrm{~cm}^{-2}\right)$ of the $\mathrm{Pt} / \mathrm{CNC}$ catalyst is higher than those of Vulcan XC-72 supported catalyst $\left(278 \mathrm{~mA} \mathrm{~cm}{ }^{-2}\right)$ and the commercial carbon supported Pt catalyst $\left(270 \mathrm{~mA} \mathrm{~cm}{ }^{-2}\right)$, respectively. At this potential and as studied in section 3.2., CNC based electrocatalysts already start to oxidise CO, whereas the electrocatalysts using Vulcan as support have not yet. The shift to a more negative potential by $\mathrm{CO}_{\text {ads }}$ oxidation on the electrocatalyst supported on $\mathrm{CNCs}$, is a key parameter in their behaviour at the anode of a PEMFC.

At $40{ }^{\circ} \mathrm{C}$, higher current and power densities were obtained, but the results follow the same trend.

Comparison with literature data is not easy due to the low platinum loading of the electrocatalysts used in this work. Andersen et al. reported current densities of $0.2 \mathrm{~A}$ $\mathrm{cm}^{-2}$ for fresh CNT and CNF Pt-supported catalyst at $70^{\circ} \mathrm{C}$ [43]. Whereas Calvillo et. al obtained maximum power densities of $27 \mathrm{~mW} \mathrm{~cm}^{-2}$ at room temperature when using CMK-3 carbons as support [44]. However, for comparing these results with the literature data, it must be taken into account that not only the temperature and pressure 
1 conditions influence the shape of the polarization curves, but also the characteristics of

2 the set-up system used for the measurements.

\section{4. Conclusions}

5 Carbon nanocoils have been proposed as an alternative material that could replace

6 carbon blacks as electrocatalytic support for low temperature fuel cells. CNC were

7 prepared by catalytic graphitization using a mixture of resorcinol-formaldehyde gel as

8 the carbon precursor and a mixture of nickel-cobalt salts as the graphitization catalysts.

9 The obtained material was used to prepare a Pt catalyst following the synthesis method of impregnation and subsequent reduction with sodium borohydride. The same method was used to prepare Vulcan supported electrocatalysts, in order to compare their 12 performance with a $\mathrm{Pt} / \mathrm{C}$ commercial catalyst from E-TEK.

13 The behaviour of the electrocatalysts on the anode side of a PEM fuel cell at room temperature and $40{ }^{\circ} \mathrm{C}$ was studied, and compared with a the commercial catalyst $\mathrm{Pt} / \mathrm{C}$ E-TEK. Results showed better performance both at room temperature and $40{ }^{\circ} \mathrm{C}$ for the CNC-supported electrocatalysts. At $0.6 \mathrm{~V}$, an increase of $4 \%$ in current density was observed at room temperature when CNCs were used as support material. Whereas the maximum power density was $13 \%$ higher for the $\mathrm{Pt} / \mathrm{CNC}$ catalysts compared with $\mathrm{Pt} / \mathrm{C}$ E-TEK. The higher electrocatalytic activity towards the anodic hydrogen oxidation is a consequence of its textural properties, like mesoporosity, and its higher tolerance to CO. This can be attributed to the carbon nanocoils used as catalyst support, which could alter the electronic structure of the metal, helping to the $\mathrm{CO}$ oxidation process.

These results are very promising, therefore, it can be concluded that CNCs are good candidates as support material for PEMFC and DMFC. The next step in the current 
1 investigations will be the preparation of bimetallic catalysts to improve the

2 performances of these materials.

\section{ACKNOWLEDGEMENTS}

5 The authors gratefully acknowledge financial support given by the Ministry of

6 Economy and Competitiveness through the Projects CTQ2011-28913-C02-01 and -02.

7 V. Celorrio also acknowledges CSIC and FSE for their JAE Grant; and the UK National

8 Academy by the support though the Newton International Fellow program.

\section{REFERENCES}

[1] Frackowiak E, Béguin F. Carbon materials for the electrochemical storage of energy in capacitors. Carbon. 2001;39:937-50.

[2] Arico AS, Bruce P, Scrosati B, Tarascon J-M, van Schalkwijk W. Nanostructured materials for advanced energy conversion and storage devices. Nature Materials. 2005;4:366-77.

[3] Wee J-H. Applications of proton exchange membrane fuel cell systems. Renewable and Sustainable Energy Reviews. 2007;11:1720-38.

[4] Kamarudin MZF, Kamarudin SK, Masdar MS, Daud WRW. Review: Direct ethanol fuel cells. Int J Hydrogen Energy. 2013;38:9438-53.

[5] Kamarudin SK, Achmad F, Daud WRW. Overview on the application of direct methanol fuel cell (DMFC) for portable electronic devices. Int J Hydrogen Energy. 2009;34:6902-16.

[6] Sergi F, Brunaccini G, Stassi A, Di Blasi A, Dispenza G, Aricò AS, et al. PEM fuel cells analysis for grid connected applications. Int J Hydrogen Energy. 2011;36:10908-16.

[7] Antolini E, Salgado JRC, Gonzalez ER. The stability of Pt-M ( $M$ = first row transition metal) alloy catalysts and its effect on the activity in low temperature fuel cells: A literature review and tests on a Pt-Co catalyst. J Power Sources. 2006;160:957-68.

[8] Álvarez G, Alcaide F, Cabot PL, Lázaro MJ, Pastor E, Solla-Gullón J. Electrochemical performance of low temperature PEMFC with surface tailored carbon nanofibers as catalyst support. Int J Hydrogen Energy. 2012;37:393-404.

[9] Postole G, Auroux A. The poisoning level of Pt/C catalysts used in PEM fuel cells by the hydrogen feed gas impurities: The bonding strength. Int J Hydrogen Energy. 2011;36:6817-25.

[10] Kim JW, Lim B, Jang H-S, Hwang SJ, Yoo SJ, Ha JS, et al. Size-controlled synthesis of Pt nanoparticles and their electrochemical activities toward oxygen reduction. Int J Hydrogen Energy. 2011;36:706-12.

[11] Yu S, Lou Q, Han K, Wang Z, Zhu H. Synthesis and electrocatalytic performance of MWCNTsupported Ag@Pt core-shell nanoparticles for ORR. Int J Hydrogen Energy. 2012;37:13365-70.

[12] Borup R, Meyers J, Pivovar B, Kim YS, Mukundan R, Garland N, et al. Scientific Aspects of Polymer Electrolyte Fuel Cell Durability and Degradation. Chem Rev. 2007;107:3904-51. 
[13] Schmittinger $W$, Vahidi A. A review of the main parameters influencing long-term performance and durability of PEM fuel cells. J Power Sources. 2008;180:1-14.

[14] Auer E, Freund A, Pietsch J, Tacke T. Carbons as supports for industrial precious metal catalysts. Applied Catalysis A: General. 1998;173:259-71.

[15] Smirnova A, Wender T, Goberman D, Hu Y-L, Aindow M, Rhine W, et al. Modification of carbon aerogel supports for PEMFC catalysts. Int J Hydrogen Energy. 2009;34:8992-7.

[16] Ambrosio EP, Francia C, Manzoli M, Penazzi N, Spinelli P. Platinum catalyst supported on mesoporous carbon for PEMFC. Int J Hydrogen Energy. 2008;33:3142-5.

[17] Antolini E. Carbon supports for low-temperature fuel cell catalysts. Applied Catalysis B: Environmental. 2009;88:1-24.

[18] Kim M, Park J-N, Kim H, Song S, Lee W-H. The preparation of Pt/C catalysts using various carbon materials for the cathode of PEMFC. J Power Sources. 2006;163:93-7.

[19] Yu X, Ye S. Recent advances in activity and durability enhancement of Pt/C catalytic cathode in PEMFC: Part I. Physico-chemical and electronic interaction between Pt and carbon support, and activity enhancement of Pt/C catalyst. J Power Sources. 2007;172:133-44.

[20] Hall SC, Subramanian V, Teeter G, Rambabu B. Influence of metal-support interaction in $\mathrm{Pt} / \mathrm{C}$ on $\mathrm{CO}$ and methanol oxidation reactions. Solid State lonics. 2004;175:809-13.

[21] Inoue M, Akamaru S, Taguchi A, Abe T. Physical and electrochemical properties of Pt-Ru/C samples prepared on various carbon supports by using the barrel sputtering system. Vacuum. 2008;83:658-63.

[22] Bezerra CWB, Zhang L, Liu H, Lee $K$, Marques ALB, Marques EP, et al. A review of heattreatment effects on activity and stability of PEM fuel cell catalysts for oxygen reduction reaction. J Power Sources. 2007;173:891-908.

[23] Shao Y, Yin G, Zhang J, Gao Y. Comparative investigation of the resistance to electrochemical oxidation of carbon black and carbon nanotubes in aqueous sulfuric acid solution. Electrochim Acta. 2006;51:5853-7.

[24] Wikander K, Ekström H, Palmqvist AEC, Lundblad A, Holmberg K, Lindbergh G. Alternative Catalysts and Carbon Support Material for PEMFC. Fuel Cells. 2006;6:21-5.

[25] Hyeon T, Han S, Sung Y-E, Park K-W, Kim Y-W. High-Performance Direct Methanol Fuel Cell Electrodes using Solid-Phase-Synthesized Carbon Nanocoils. Angew Chem Int Ed. 2003;42:4352-6.

[26] Marie J, Berthon-Fabry S, Achard P, Chatenet M, Pradourat A, Chainet E. Highly dispersed platinum on carbon aerogels as supported catalysts for PEM fuel cell-electrodes: comparison of two different synthesis paths. J Non-Cryst Solids. 2004;350:88-96.

[27] Calvillo L, Lázaro MJ, García-Bordejé E, Moliner R, Cabot PL, Esparbé I, et al. Platinum supported on functionalized ordered mesoporous carbon as electrocatalyst for direct methanol fuel cells. J Power Sources. 2007;169:59-64.

[28] Celorrio V, Calvillo L, Martínez-Huerta MV, Moliner R, Lázaro MJ. Study of the Synthesis Conditions of Carbon Nanocoils for Energetic Applications. Energy Fuels. 2010;24:3361-5.

[29] Celorrio V, Calvillo L, Pérez-Rodríguez S, Lázaro MJ, Moliner R. Modification of the properties of carbon nanocoils by different treatments in liquid phase. Micropor Mesopor Mater. 2011;142:55-61.

[30] Salgado JRC, Antolini E, Gonzalez ER. Structure and Activity of Carbon-Supported Pt-Co Electrocatalysts for Oxygen Reduction. The Journal of Physical Chemistry B. 2004;108:1776774.

[31] Zhou J-H, He J-P, Ji Y-J, Dang W-J, Liu X-L, Zhao G-W, et al. CTAB assisted microwave synthesis of ordered mesoporous carbon supported Pt nanoparticles for hydrogen electrooxidation. Electrochim Acta. 2007;52:4691-5.

[32] Li W, Zhou W, Li H, Zhou Z, Zhou B, Sun G, et al. Nano-stuctured Pt-Fe/C as cathode catalyst in direct methanol fuel cell. Electrochim Acta. 2004;49:1045-55. 
[33] Calvillo L, Celorrio V, Moliner R, Garcia AB, Caméan I, Lazaro MJ. Comparative study of Pt catalysts supported on different high conductive carbon materials for methanol and ethanol oxidation. Electrochim Acta. 2013;102:19-27.

[34] Salgado JRC, Quintana JJ, Calvillo L, Lazaro MJ, Cabot PL, Esparbe I, et al. Carbon monoxide and methanol oxidation at platinum catalysts supported on ordered mesoporous carbon: the influence of functionalization of the support. PCCP. 2008;10:6796-806.

[35] Antolini E, Salgado JRC, Santos LGRA, Garcia G, Ticianelli EA, Pastor E, et al. Carbon supported $\mathrm{Pt}-\mathrm{Cr}$ alloys as oxygen-reduction catalysts for direct methanol fuel cells. J Appl Electrochem. 2006;36:355-62.

[36] Celorrio V, Plana D, Florez J, Montes-de-Oca M, Moore A, Lázaro MJ, et al. Methanol Oxidation at Diamond-Supported Pt Nanoparticles: Effect of the Diamond Surface Termination. The Journal of Physical Chemistry C. 2013.

[37] Maillard F, Eikerling M, Cherstiouk OV, Schreier S, Savinova E, Stimming U. Size effects on reactivity of $\mathrm{Pt}$ nanoparticles in $\mathrm{CO}$ monolayer oxidation: The role of surface mobility. Faraday Discuss. 2004;125:357-77.

[38] Hayden BE, Pletcher D, Suchsland J-P, Williams L. The influence of support and particle size on the platinum catalysed oxygen reduction reaction. PCCP. 2009;11:9141-8.

[39] Cherstiouk OV, Simonov PA, Savinova ER. Model approach to evaluate particle size effects in electrocatalysis: preparation and properties of Pt nanoparticles supported on GC and HOPG. Electrochim Acta. 2003;48:3851-60.

[40] Guerin S, Hayden BE, Lee CE, Mormiche C, Owen JR, Russell AE, et al. Combinatorial Electrochemical Screening of Fuel Cell Electrocatalysts. J Comb Chem. 2003;6:149-58.

[41] Scherer GG. Interfacial aspects in the development of polymer electrolyte fuel cells. Solid State lonics. 1997;94:249-57.

[42] O'Hayre R, Barnett DM, Prinz FB. The Triple Phase Boundary: A Mathematical Model and Experimental Investigations for Fuel Cells. J Electrochem Soc. 2005;152:A439-A44.

[43] Andersen SM, Borghei M, Lund P, Elina Y-R, Pasanen A, Kauppinen E, et al. Durability of carbon nanofiber (CNF) \& carbon nanotube (CNT) as catalyst support for Proton Exchange Membrane Fuel Cells. Solid State lonics. 2013;231:94-101.

[44] Calvillo L, Gangeri M, Perathoner S, Centi G, Moliner R, Lázaro MJ. Synthesis and performance of platinum supported on ordered mesoporous carbons as catalyst for PEM fuel cells: Effect of the surface chemistry of the support. Int J Hydrogen Energy. 2011;36:9805-14. 


\section{FIGURE CAPTIONS}

2 Figure 1. XRD diffractograms for the carbon materials used as supports (a) and for the

3 Pt electrocatalysts supported on CNCs and Vulcan XC-72R, including the commercial

4 catalyst (b).

5

6 Figure 2. TEM images of the $\mathrm{Pt} / \mathrm{CNC}$ catalyst.

7

8 Figure 3. CO-stripping voltammograms for the Pt electrocatalysts in $0.5 \mathrm{M} \mathrm{H}_{2} \mathrm{SO}_{4}$. Ead $=$ $9 \quad 0.20 \mathrm{~V} ; \mathrm{v}=0.020 \mathrm{~V} \mathrm{~s}^{-1} ; \mathrm{T}=25^{\circ} \mathrm{C}$.

10

11 Figure 4. Comparison of the polarization curves and power densities obtained using the different Pt electrocatalyst at room temperature (a) and $40{ }^{\circ} \mathrm{C}(\mathrm{b})$ as anodes in a PEM 13 fuel cell. 
(a)

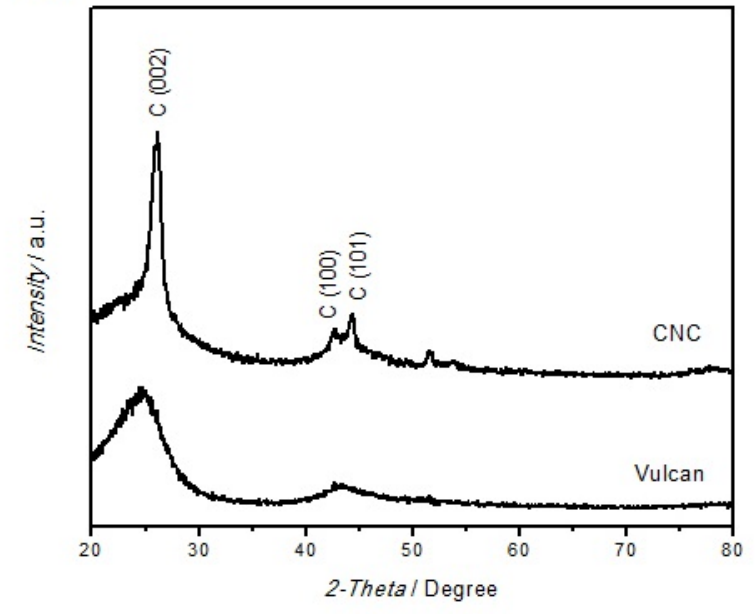

(b)

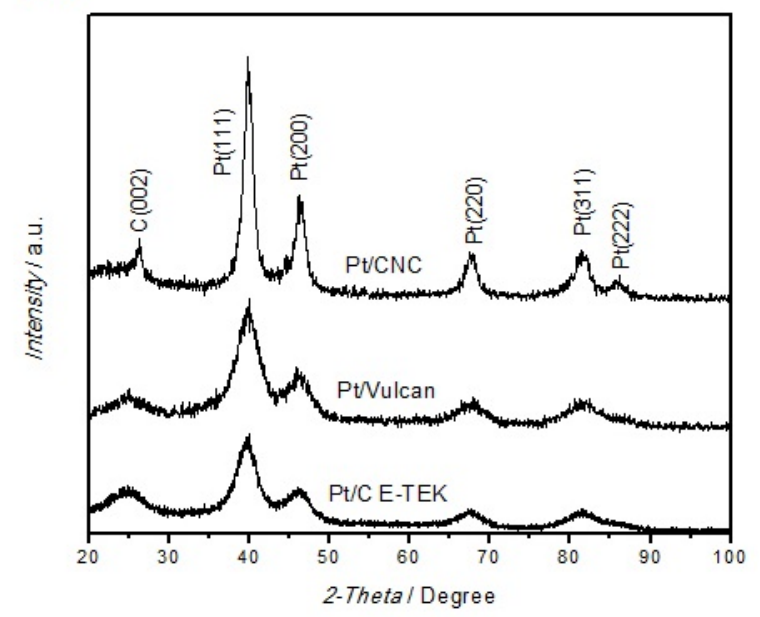

7 Figure 1

8

9

10

11

12

13

14

15

16

17

18

19

20

21

22

23

24

25 


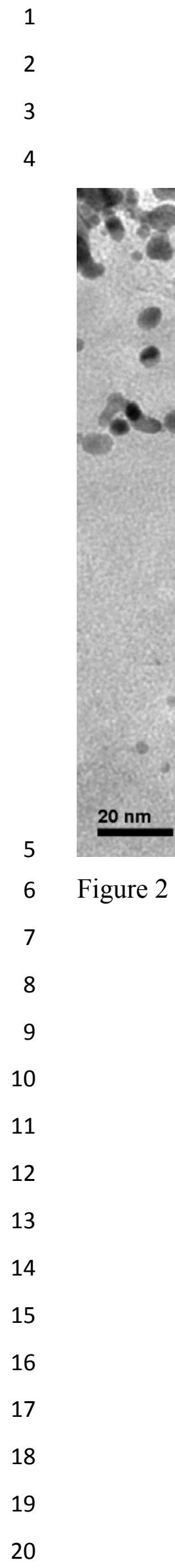




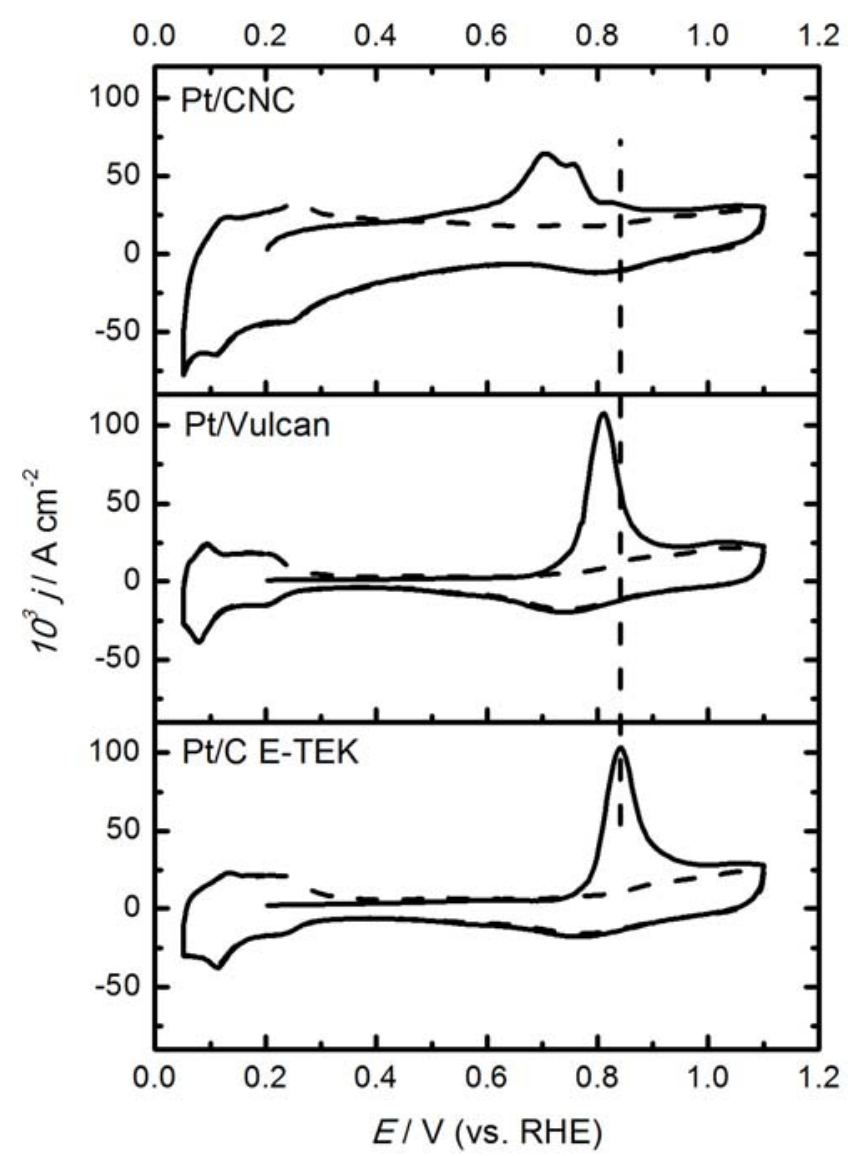

5

6 Figure 3

7

8

9

10

11

12

13 
1

2

3

4

(a)

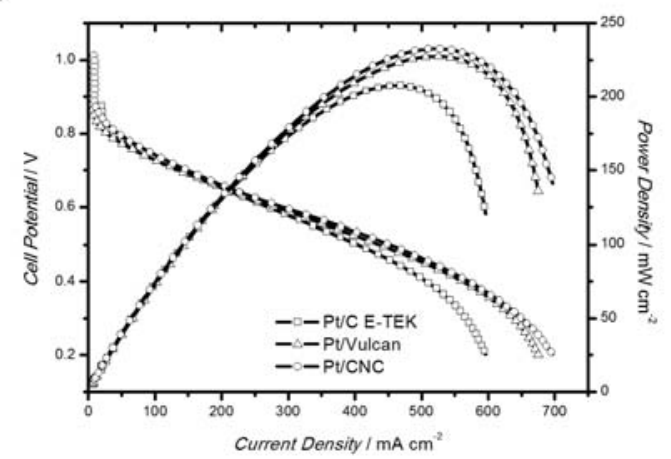

5

$6 \quad$ Figure 4

7

8

9

10

11

12

13

14

15

16

17

18

19

20

21

22

23

24

25

26

27

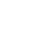

政

.

.

4

15

6

7

18

19

22

23

24

5

6 (b)

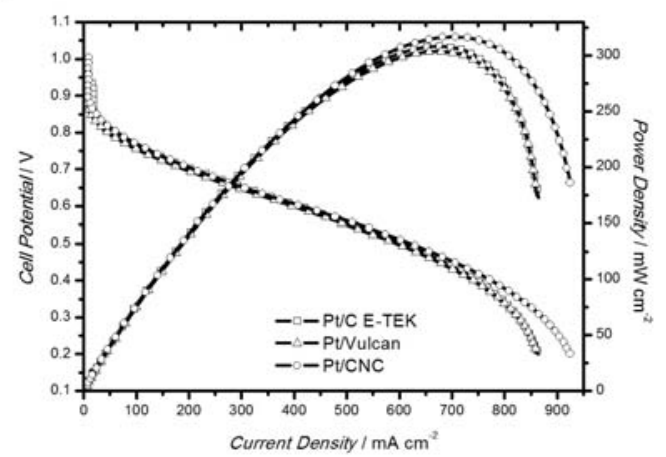

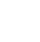


2

3 TABLE 1. Total metal content obtained from EDX analysis and physical characteristics

4 of the catalysts obtained from XRD analysis.

5

\begin{tabular}{lccc}
\hline Catalyst & $\begin{array}{c}\text { wt.\% Total } \\
\text { metal content }\end{array}$ & $\begin{array}{c}\text { Average crystallite size } \\
(\mathrm{nm})\end{array}$ & $\begin{array}{c}\text { Lattice parameter } \\
\end{array}$ \\
& 20.0 & 4.7 & 3.9158 \\
\hline $\mathrm{Pt} / \mathrm{CNC}$ & 19.2 & 3.2 & 3.9198 \\
$\mathrm{Pt} /$ Vulcan & 16.3 & 3.0 & 3.9271 \\
$\mathrm{Pt} / \mathrm{C}$ E-TEK & & & \\
\hline
\end{tabular}

6

7

8 